\title{
Massoud Azarnush. "The Archaeological Excavation at Qal'eh-i Yāzdgird: Gach Gonbad West)/[Kāvošhāy-e Bāstānšenāsì -e Qāl'eh Yāzdgerd: Gāč Gonbād-e Ghārbì]"
}

\section{Parsa Ghasemi}

\section{(2) OpenEdition}

\section{Journals}

Electronic version

URL: http://journals.openedition.org/abstractairanica/50213

DOI: $10.4000 /$ abstractairanica. 50213

ISBN: 1961-960X

ISSN: 1961-960X

\section{Publisher:}

CNRS (UMR 7528 Mondes iraniens et indiens), Éditions de l'IFRI

\section{Electronic reference}

Parsa Ghasemi, "Massoud Azarnush. "The Archaeological Excavation at Qal'eh-i Yāzdgird: Gach Gonbad West)/[Kāvošhāy-e Bāstānšenāsì -e Qāl'eh Yāzdgerd: Gāč Gonbād-e Ghārbī]"', Abstracta Iranica [Online], Volume 40-41 | 2019, document 55, Online since 30 December 2019, connection on 21 April 2021. URL: http://journals.openedition.org/abstractairanica/50213 ; DOI: https://doi.org/10.4000/ abstractairanica. 50213

This text was automatically generated on 21 April 2021.

Tous droits réservés 
Massoud Azarnush. "The Archaeological Excavation at Qal'ehi Yāzdgird: Gach Gonbad West)/ [Kāvošhāy-e Bāstānšenāsì -e Qāl'eh Yāzdgerd: Gāč Gonbād-e Ghārbỉ]"

\author{
Parsa Ghasemi
}

\title{
REFERENCES
}

Massoud Azarnush. “The Archaeological Excavation at Qal'eh-i Yāzdgird: Gach Gonbad West)/[Kāvošhāy-e Bāstānšenāsì -e Qāl'eh Yāzdgerd: Gāč Gonbād-e Ghārbī]", Bāstānšenāsi (Journal of the Iranian Center for Archaeological Research) $1 / n^{\circ} 1,2018, p$.

105-118 (in Persian)

1 The Archaeological site of Qal'eh-i Yazdgird (Keall, Iran V, 1967, 99-121) with an area of about $30 \mathrm{~km}^{2}$ is located at BānZardeh Village, Dālāhou county of Kermānšāh Province. Apart from the fortification wall, JāyDār and Gāč Gonbād (Meydān) are among the most diagnostic remains of this site. The archaeological evidence shows that this site was one of the important fortified sites founded by the Parthian (250 BC-226 AD) and continued to be occupied during the Sasanian and early Islamic periods. Qal'eh Dāvār and its complex is the diagnostic Sasanian dated monument of the site. Edward Keall was the first who excavated the Qal'eh-i Yazdgird between 1975 to 1979 (Keall, Proc. $4^{\text {th }}$ Annual Symposium of Archaeological Research in Iran 1976, 380-390; Keall, Iran XV, 1977, 1-9; Keall, Iran, XX, 1982, 51-72).

2 In 2007, after a twenty-year halt due to the Iranian Islamic revolution, the first season of archaeological excavation in the second round was carried out by the late Māșsoūd Āzarnūsh. He continued to excavate the Gāč Gonbād-e Ghārbi, where Edward Keall has 
already found the regular and important remains of Parthian architecture. In this paper written shortly before his sudden death in 2008, M. Ázarnūsh describes the architectural finds in this season of excavation. The unearthed architecture consists of eight separate units dated to the late Parthian periods which are numerated 1-8. The units 1-6 have a similar regular rectangular plan and very similar to one another, however, their length are three times larger than their width. Based on the large quantities of the debris of bricks on the floor of rooms, he assumed that these units were covered by vault made of baked bricks, and probably the height of the unites walls were between 3 and $4 \mathrm{~m}$. We do hope one of his team members or colleagues would publish the archaeological finds of this excavation, which is extremely important to the poorly studied Parthian archaeology in the Iranian plateau.

\section{AUTHORS}

\section{PARSA GHASEMI}

Doctorant Archéologie, Université Paris-Nanterre 